\title{
Evidence for seismogenic hydrogen gas, a potential microbial energy source on Earth and Mars
}

\author{
Sean McMahon \\ sean.mcmahon@yale.edu \\ Department of Geology \& Geophysics, Yale University, \\ 210 Whitney Avenue, New Haven, CT, USA \\ +1 (203) 432-5411 \\ John Parnell \\ Department of Geology \& Petroleum Geology, \\ School of Geosciences, University of Aberdeen, UK \\ Nigel J. F. Blamey \\ Department of Earth Sciences, Brock University, Canada
}

\begin{abstract}
The oxidation of molecular hydrogen $\left(\mathrm{H}_{2}\right)$ is thought to be a major source of metabolic energy for life in the deep subsurface on Earth, and could likewise support any extant biosphere on Mars, where stable habitable environments are probably limited to the subsurface. Faulting and fracturing may stimulate the supply of $\mathrm{H}_{2}$ from several sources. We report the $\mathrm{H}_{2}$ content of fluids present in terrestrial rocks formed by brittle fracturing on fault planes (pseudotachylites and cataclasites), along with protolith control samples. The fluids are dominated by water and include $\mathrm{H}_{2}$ at abundances sufficient to support hydrogenotrophic microorganisms, with strong $\mathrm{H}_{2}$ enrichments in the pseudotachylites compared to the controls. Weaker and less consistent $\mathrm{H}_{2}$ enrichments are observed in the cataclasites, which represent less intense seismic friction than the pseudotachylites. The enrichments agree quantitatively with previous experimental measurements of frictionally driven $\mathrm{H}_{2}$ formation during rock fracturing. We find that conservative estimates of current martian global seismicity predict episodic $\mathrm{H}_{2}$ generation by Marsquakes in quantities useful to hydrogenotrophs over a range of scales and recurrence times. On both Earth and Mars, secondary release of $\mathrm{H}_{2}$ may also accompany the breakdown of ancient fault rocks, which are particularly abundant in the pervasively fractured martian crust. This study strengthens the case for the astrobiological investigation of ancient martian fracture systems.
\end{abstract}

Key words: Deep biosphere, faults, fault rocks, seismic activity, hydrogen, Mars 


\section{Introduction}

The oxidation of molecular hydrogen $\left(\mathrm{H}_{2}\right)$ is an important energy source and carbon fixing process in anaerobic ecosystems, and may have powered the earliest life on Earth (e.g. Kral et al., 1998; Schulte et al., 2006; Sleep et al., 2011; Lane \& Martin, 2012). Methanogenesis, acetogenesis and sulphate reduction are among the hydrogenotrophic metabolic pathways highlighted as the most plausible strategies for life on Mars (e.g. Nixon et al., 2013), partly because terrestrial volcanic aquifers analogous to those thought to occur in the martian subsurface are populated by such hydrogenotrophs (Stevens \& McKinley, 1995; Chapelle et al., 2002).

On both planets, water-rock reactions and groundwater radiolysis may generate high enough concentrations of $\mathrm{H}_{2}$ in the subsurface to sustain microbial hydrogenotrophy (e.g. McCollom, 1999; Chapelle et al., 2002; Lin et al., 2005; Onstott et al., 2006; Blair et al., 2007; Nixon et al., 2013). Faulting and fracturing may locally accelerate these processes by exposing fresh rock surfaces to groundwater. It may also both generate and liberate hydrogen from minerals; a number of studies have demonstrated experimentally that $\mathrm{H}_{2}$ evolves during the crushing or grinding of rocks and minerals. Among these, Freund et al. (2002) report a passive role for cracking and fissuring in accelerating the outwards diffusion of $\mathrm{H}_{2}$ from interstitial sites in crystalline rocks, where it can form during cooling from the redox conversion of $\mathrm{OH}^{-}$into peroxy defects and $\mathrm{H}_{2}$ (ibid., and references therein). Kita et al. (1982) described an active role for frictional grinding (on a fault plane) in generating silicon radical species that react rapidly with water to yield $\mathrm{H}_{2}$, a process represented by the summary reaction:

$$
2(\equiv \mathrm{Si} \cdot)+2 \mathrm{H}_{2} \mathrm{O} \rightarrow 2(\equiv \mathrm{SiOH})+\mathrm{H}_{2}
$$


Experimental support for this "mechanoradical" mechanism was furnished by Saruwatari et al. (2004), while Hirose et al. (2011) showed that frictional grinding liberates $\mathrm{H}_{2}$ from a range of silicate and non-silicate rocks (as a function of the friction applied), and that even dry basalt (maintained at $100^{\circ} \mathrm{C}$ for two weeks to expel intergranular water) generates $\mathrm{H}_{2}$ under friction, probably derived from crystallographic water. In support of these experimental results, an association between earthquake activity and high fluxes of $\mathrm{H}_{2}$ has been observed in natural fault zones (Wakita et al., 1980; Wiersberg \& Erzinger, 2008). Both Freund et al. (2002) and Hirose et al. (2011) have suggested that this earthquake-generated (or earthquake-liberated) $\mathrm{H}_{2}$ might fuel pockets of microbial activity around faults on Earth; Michalski et al. (2013) extrapolated this proposal to Mars.

The present study aimed to determine: (1) whether the unique rock-types produced by faulting contain molecular hydrogen, and if so: (2) whether the $\mathrm{H}_{2}$ and $\mathrm{H}_{2} \mathrm{O}$ contents of these rocks, if representing original pore fluids, would imply a hydrogen concentration sufficient to support microbial hydrogenotrophy, and (3) whether the empirical model of frictionally controlled $\mathrm{H}_{2}$ release during earthquakes furnished by Hirose et al. (2011) is quantitatively appropriate to suggest an explanation for the measured enrichments. We then asked (4) whether biologically significant quantities of hydrogen are predicted by this model when applied to the present-day subsurface of Mars. 


\subsection{Measurement of $\mathrm{H}_{2}$ in fault rocks}

Movement on fault planes generates two unique rock types: cataclasites and pseudotachylites. Cataclasites are fault breccias, comprising angular clasts of wall rock in a comminuted finegrained matrix; these rocks are produced by brittle fracturing and grinding during seismic activity. Pseudotachylites (also spelled "pseudotachylytes") are glassy or very fine grained fault rocks formed under more intense friction by melting; the molten rock forms under pressure along fractures and other planes of weakness, often flows considerable distances, and quenches rapidly to form dyke- or vein-like structures (Macloughlin \& Spray, 1992). Pseudotachylites on faults represent planes of weakness along which new fractures propagate to accommodate tectonic strain, and typically show complex, fractured microstructures indicative of brittle deformation (e.g. Wenk, 1978; Kirkpatrick \& Rowe, 2013).

Faulted rocks commonly contain healed microfractures bearing ancient fault-zone fluids (e.g. Lespinasse \& Cathelineau, 1990; Anders et al., 2014). In the present study, cataclasites and pseudotachylites were crushed to evacuate fluids for sampling by a mass spectrometer. The cataclasites were collected from Cambrian quartzites associated with the Moine Thrust Belt in Scotland. Impact-related pseudotachylites were collected from two very large Precambrian crater structures - the Sudbury Crater in Canada (granite host) and the Vredefort Crater in South Africa (quartzite host)—and non-impact-related pseudotachlites were recovered from Permian granite in the Isles of Scilly (UK) and Precambrian gneiss in the Outer Hebrides of Scotland. Control samples representative of the original pre-faulting lithologies were collected from the Outer Hebrides, the Moine Thrust Belt, and the Isles of Scilly, with an additional Precambrian quartzite sourced from Kiruna in northern Sweden. 
We analysed the bulk fluid content of our samples using the CFS mass spectrometry technique previously used by our team to liberate and analyse volatiles from serpentinites, mineral veins, basalts, and most recently martian meteorites (Parnell et al., 2010; McMahon et al. 2012; McMahon et al. 2013; Blamey et al., 2015). This method involves crushing the sample and immediately passing the volatiles released through a quadrupole mass spectrometer, and offers very low detection limits. 


\section{Methods}

\subsection{Materials}

The fault-rock samples are tabulated in Table 1. Two of the pseudotachylite samples were collected from Earth's two largest known impact structures, the 1.85-Ga Sudbury crater in Canada and the 2.02-Ga Vredefort structure in South Africa. Control samples were unfortunately not recovered from the crater localities. The remaining psuedotachylites and appropriate control samples were collected from the Outer Hebrides and the Gairloch region in Northwest Scotland, and the Isles of Scilly, all in the UK.

The Sudbury crater spans about $70 \mathrm{~km}$ and is tectonically distorted into an elliptical shape (Figure 1a). Pseudotachylites occur as the matrix in the "Sudbury breccia", which forms a 15km-wide collar around the Sudbury Igneous Complex (SIC). The sample analysed here was collected by Alison Wright from granite host rock near Creighton in the Creighton Pluton, adjacent to the SIC. The Vredefort structure, which occurs within the Witwatersrand Basin, is much larger, spanning $250 \mathrm{~km}$. Pseudotachylites occur here as veins and dykes on scales from $\mathrm{mm}$ to tens of $\mathrm{m}$ within the central Vredefort Dome, which represents the central uplift of the original crater (Riller et al., 2010). The sample analysed in the present study was donated by Roger L. Gibson, who collected it from a quartzite unit in the Witwatersrand Supergroup, at a locality about $10 \mathrm{~km} \mathrm{NNW}$ from the town of Parys, towards the edge of the Vredefort Dome (Figure $1 \mathbf{b}$ ). It has been suggested that the Sudbury and Vredefort pseudotachylites are impact melts injected across large distances rather than local frictional melts derived from the fault walls (Riller et al., 2010). However, both impact-related and non-impact-related pseudotachylites are rich in healed microfractures and other microstructural features indicative of brittle deformation 
and cataclasis and as such may contain $\mathrm{H}_{2}$ and other fluids trapped during fault motion (e.g. Wenk, 1978; Boullier et al., 2001; Lafrance \& Kamber, 2010).

The samples from the Outer Hebrides were collected on the islands of Barra, South Uist and North Uist, and represent pseudotachylites of the Outer Hebrides Fault Zone (OHFZ), which runs about $170 \mathrm{~km} \sim \mathrm{N}-\mathrm{S}$ down the eastern seaboard of the islands (Figure 2). Pseudotachylites in this region are hosted by the Late Archean/Early Palaeoproterozoic Lewisian Gneiss, and appear to have been formed during several different fault reactivation events during the Precambrian, including one at $\sim 1250 \mathrm{Ma}$ and one at $\sim 700 \mathrm{Ma}$ (Sherlock et al., 2008). Pseudotachylites recovered from coastal exposures on Barra are illustrated by Figure $\mathbf{3}$ and were found to contain healed microfractures probably representing brittle deformation during fault reactivation.

Pseudotachylites in the Gairloch region on the northwest Scottish mainland are also hosted by Lewisian Gneiss but are associated with a different fault system and have been dated to around 1 Ga (Sherlock et al., 2008). The samples analysed here were collected from the Loch Tollie Quarry, west of Loch Tollie, and from a second locality to the east of Loch Tollie, where the control gneiss sample was also collected. The loch lies between two "crush belts" (shear zones) about $1 \mathrm{~km}$ distant to the NE and SW (Sherlock et al., 2008; Figure 4). Each of the Scottish pseudotachylite occurrences consists of glassy black vein networks up to metres in width, containing fragments of unaltered gneiss country rock. The pseudotachylites are locally cut by planar quartz veins, representing brittle reactivation of the fault system. Samples from the Loch 
Tollie localities contain pyrite up to $1 \mathrm{~mm}$ size, particularly around healed microfractures (Figure 5).. The analyses were made of glassy material free of country rock, quartz or pyrite.

The Isles of Scilly are located about $50 \mathrm{~km}$ WSW from the westernmost point of mainland Cornwall, England. They are dominated by a large Hercynian (Permo-Carboniferous) granite pluton, with superficial sedimentary cover. As far as we can discover, pseudotachylite has not previously been described in the Isles of Scilly, although Barrow \& Flett (1906) refers to "greisen veins" in the granite, by which the pseudotachylite may be intended. The samples analysed here were collected from float material of granitic rock cut by centimetres-width black, glassy veins on a beach on St. Agnes Island where the pseudotachylite can also be seen in situ (Figure 3B). The control granite (predominantly quartz and feldspar, identical to the pseudotachylite host rock) was also collected at this locality.

Cambrian cataclasites (originally quartzites) were sampled from faults associated with the Moine Thrust Belt in the vicinity of Ullapool in western Scotland (Figure 4). Each of the Cambrian samples was originally a quartz arenite (almost pure quartz sandstone), consisting of rounded grains of medium-coarse quartz sand, cemented by quartz overgrowths, such that there is negligible residual porosity. This large and structurally complex thrust zone developed during the Caledonian orogeny around 450-430 Ma (Goodenough et al., 2011), and extends for nearly $200 \mathrm{~km}$. Samples were collected by the present authors from a beach outcrop near Achiltibuie, a roadcut at Skiag Bridge, the mountain Conival near Inchnadamph and a roadcut at Corry Bridge near Ullapool. Skiag Bridge is a well-known locality close to the shore of Loch Assynt, where the Cambrian Pipe Rock quartzite is offset by a minor thrust fault, with "damage zones" on both 
sides (Lloyd, 2000). The Conival sample is from a crushed zone in which brecciated quartzite fragments are cemented by a matrix rich in iron oxide and kaolinite. The Corry Bridge exposure (on the A835 road) is also a well-known locality, where fractured Cambrian quartzite outcrops along a fault where rocks of the Proterozoic Torridonian Supergroup are thrusted over limestone of the Ordovician Durness Group (Allison et al., 1988). Five control samples for the cataclasite analyses were selected from a range of Cambrian quartzites from western Scotland and an additional specimen was sampled from the Palaeoproterozoic Hauki Quartzite at Kiruna, Sweden. The control sample from Coulags is conspicuously veined by quartz as a result of Moine Thrust deformation, but is not a cataclasite (and the quartz veins themselves were excluded from the analysed portion). The sample from Ord, Isle of Skye, was obtained from close to a thrust fault, but is not a cataclasite. 


\subsection{Crush-fast-scan mass spectrometry}

Samples were extracted from the interiors of rock specimens using a water-lubricated diamond circular saw to avoid (as far as possible) superficially weathered and contaminated material. Match-head-sized samples of about $250 \mathrm{mg}$ were obtained by crushing specimens with a stainless steel fly-press scrubbed clean with acetone. Samples were rinsed in hydrogen peroxide, potassium hydroxide and deionized water to remove superficial organic matter and dried in a laminar flow hood before sealing in sterile plastic bags for shipping.

Volatiles were extracted and analysed at the New Mexico Institute of Technology using the crush-fast-scan (CFS) mass-spectrometry technique (Norman \& Moore, 1997; Moore et al., 2001; Parry \& Blamey, 2010; Blamey, 2012; Blamey et al. 2015). Samples were crushed incrementally under an ultra-high vacuum $\left(\sim 10^{-8}\right.$ Torr $)$, with each crush liberating a swift burst of mixed volatiles. Each crush increment may liberate fluids from multiple sites. A typical sample size of about $250 \mathrm{mg}$ released four to ten bursts of volatiles into the vacuum chamber, which remained there for $8-10$ analyser scans ( $\sim 2$ seconds) before removal by the vacuum pump. This method does not require a carrier gas and volatiles are not separated from each other but released simultaneously into the chamber. The crushing area and crushing bellows were cleaned with potassium hydroxide and swabbed with de-ionized water and isopropanol prior to analysis. Crushing of fused silica cuvettes with low gas-content ("blanks" used to support the analysis of geological samples) produces a burst of hydrogen three-to-four orders of magnitude smaller than that released from fluid inclusions in rocks; these bursts are likely to represent trace gases already present in the blanks. 


\section{Results}

The main constituents of the evacuated fluids were $\mathrm{H}_{2}, \mathrm{~N}_{2}, \mathrm{CO}_{2}$, and $\mathrm{H}_{2} \mathrm{O}$ (Table 2), with most samples dominated by water (typically $>90 \%$ ). $\mathrm{CO}_{2}$ was the most abundant of the non-water phases. All pseudotachylites with local country rock controls were enriched in $\mathrm{H}_{2}$ compared to the controls. For comparison with model predictions and microbial requirements expressed as aqueous concentrations, we report $\mathrm{H}_{2}$ relative to $\mathrm{H}_{2} \mathrm{O}\left(\mathrm{mol} \mathrm{dm}{ }^{-3}\right.$ ) using the $\mathrm{H}_{2} \mathrm{O}$ and $\mathrm{H}_{2}$ percentages; however, the measured values generally exceed the solubility of $\mathrm{H}_{2}$ in water under standard conditions $(\sim 0.8 \mathrm{mM})$, indicating that some hydrogen is actually present in a free gas phase coexistent with water. (An almost identical overall distribution of results is found if $\mathrm{H}_{2} / \mathrm{N}_{2}$ or $\% \mathrm{H}_{2}$ is considered.) Results for the pseudotachylites are shown in Figure 6A. $\mathrm{H}_{2}$ abundance per volume of water in the pseudotachylites ranged from $1.9 \times 10^{-2} \mathrm{~mol} \mathrm{dm}^{-3}$ (an outlier) to 8.3

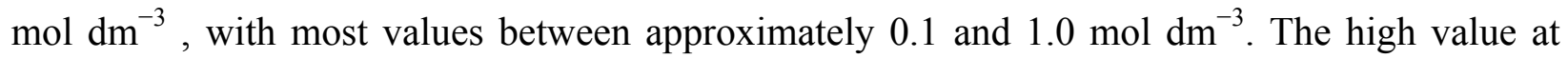
Barra Quarry $\left(1.1 \% \mathrm{H}_{2}\right.$ or $\left.6.2 \mathrm{~mol} \mathrm{dm}^{-3}\right)$ should be interpreted with caution because the fluids from this sample were uniquely dominated by $\mathrm{CO}_{2}$ rather than water. Country-rock controls ranged from 0.4 to $5.3 \times 10^{-2} \mathrm{~mol} \mathrm{dm}{ }^{-3}$. The average enrichment in $\mathrm{H}_{2}$ enrichment in the pseudotachylites compared to the controls was $1.3 \mathrm{~mol} \mathrm{dm}{ }^{-3} \mathrm{H}_{2} \mathrm{O}$ in the Outer Hebrides gneiss ( $0.4 \mathrm{~mol} \mathrm{dm}^{-3}$ if Barra Quarry is excluded), $0.13 \mathrm{~mol} \mathrm{dm}^{-3}$ in the gneiss west of Loch Tollie, $1.1 \mathrm{~mol} \mathrm{dm}^{-3}$ in the gneiss east of Loch Tollie and $4.6 \mathrm{~mol} \mathrm{dm}^{-3}$ in the granite from St Agnes Island. No significant difference in $\mathrm{H}_{2}$ abundance was observed between the tectonic and the impact-crater pseudotachylites, although suitable controls were not available for comparison with the latter. The two pseudotachylites from the western locality at Tollie, Gairloch are over an order of magnitude discrepant; the higher of the two samples is closer to the pseudotachylites from other localities. 
Results for the cataclasites are shown in Figure 6B. The $\mathrm{H}_{2}$ enrichments are slightly higher on average in the cataclasites than the local quartzite controls but lower than those detected in most of the pseudotachylites. The average $\mathrm{H}_{2}$ enrichment in the cataclasites compared to the local controls was $0.18 \mathrm{~mol} \mathrm{dm}^{-3}\left(\mathrm{H}_{2} \mathrm{O}\right)$. 


\section{Discussion}

The gas analysis shows that the pseudotachylites are consistently enriched in hydrogen compared to suitable controls, while an enrichment in the cataclasites is more equivocally suggested. Notably, there is no evidence of hydrogen enrichment in the cataclasite sample from the minor thrust at Skiag Bridge compared to the non-cataclasite quartzite from the same locality. However, it may be significant that the Corry Bridge cataclasite, which is particularly well developed and has been described as "ultracataclasite" (Allison et al., 1988), yields the highest $\mathrm{H}_{2}$ abundance among the cataclasites we analysed.

\subsection{Possible sources of measured hydrogen}

The rocks are of low permeability and the exposures sampled are not close to mafic or ultramafic rocks, to serpentine- or talc-bearing units, or to organic-rich sediments from which $\mathrm{H}_{2}$ might otherwise have been derived. Radiolysis and water-rock reactions are the most widely discussed mechanisms for generating $\mathrm{H}_{2}$ within rocks. Radiolysis over long timescales has previously been suggested to account for most of the $\mathrm{H}_{2}$ in Precambrian basement, although we find $\mathrm{H}_{2}$ enrichments in the Phanerozoic pseudotachylites comparable to those in the more ancient samples, and the Palaeoproterozoic quartzite sample analysed (Kiruna, northern Sweden) is poorer in $\mathrm{H}_{2}$ than most of the Cambrian samples. Water-rock reactions capable of generating $\mathrm{H}_{2}$ during the oxidation of ferrous iron are well known in mafic and ultramafic igneous rocks but have not been widely described in gneiss or granite (which do nevertheless contain some ferrous iron, e.g. in biotite). 
The sampled rocks must have lost some $\mathrm{H}_{2}$ by diffusion over geological time, but the non-fault rocks should not have lost substantially more $\mathrm{H}_{2}$ than the fault rocks; nor should the cataclasites have lost more than the pseudotachylites. Hence, the $\mathrm{H}_{2}$ enrichment in the fault rocks compared to the controls implies a process of faulting-related $\mathrm{H}_{2}$ production or release. The fact that pseudotachylites are found to record a greater $\mathrm{H}_{2}$ enrichment than cataclasites supports this inference, since the former represent a greater intensity of fault activity and, being glassy or very fine-grained, are especially vulnerable to disruption, including microfracturing, during fault reactivation (Kirkpatrick \& Rowe, 2013)._However, the difference between the $\mathrm{H}_{2}$ content of the two rock types may be less significant than the differing tectonic and lithological settings of the particular localities sampled, particularly the fact that the faults sampled for cataclasites had smaller displacements.

Faulting stimulates both water-rock reactions and radiolysis by exposing fresh rock surfaces to groundwater (e.g. Sherwood Lollar et al., 2007; Sleep., 2012), but the addition of water through fractures would not necessarily increase the amount of $\mathrm{H}_{2}$ per volume of water as recorded in our samples. Moreover, these are slow processes, whereas $\mathrm{H}_{2}$ generated rapidly at the time of fault motion should be more abundantly trapped (in concurrently propagating microfractures). Such rapid fracture-enhanced processes include the diffusion of existing $\mathrm{H}_{2}$ out of interstitial sites in crystals (Freund et al. 2002) and the mechanoradical mechanism described by Kita et al. (1982) and Hirose et al. (2011). The melting of the pseudotachylite would only have led to minimal $\mathrm{H}_{2}$ formation because, given the absence of organic matter and graphite, conditions were insufficiently reducing. However, while a crystalline rock is cooling after crystallisation, the redox conversion of $\mathrm{OH}^{-}$into peroxy defects and $\mathrm{H}_{2}$ can occur (Freund et al. 2002 and references 
therein). This may have contributed some portion of the $\mathrm{H}_{2}$ we measured in the pseudotachylites, which would be retained interstitially independently of any fluid inclusions trapping original pore fluids from the fault zone. Additional fluids, including water, may have been exsolved during cooling after crystallization both of the pseudotachylites and of their precursor crystalline rocks, forming inter- and intragranular fluid-filled cavities.

Assuming that the fluids we measured in the pseudotachylites mostly represent original porewater trapped in microfractures during faulting activity, we now ask whether the measured $\mathrm{H}_{2}$ enrichments are broadly consistent with the measurements made by Hirose et al. (2011) of gas liberated during the grinding-together of rock surfaces. From these measurements, Hirose et al. derived a semi-empirical equation describing the concentration of mechanically derived $\mathrm{H}_{2}$ in fault-zone porewater immediately after an earthquake:

$$
\left[H_{2}\right]_{\text {local }}=\frac{10^{2} \alpha \sigma_{e f f} \mu_{d}}{\phi}
$$

where $\alpha$ is an empirical coefficient describing the slope of the graph of hydrogen production against frictional work; $\sigma_{e f f}$ is the effective stress acting on the fault surface, $\mu_{d}$ is the average dynamic friction coefficient during fault motion and $\phi$ is the average porosity. The use of this equation assumes that (1) all pore-spaces in the original fault zone are filled with fluid, and (2) there is negligible fluid flow over the recurrence time of the seismic motion. These variablesand therefore the estimate of $\mathrm{H}_{2}$ concentration - are independent of event magnitude. It should be noted that the "concentration" calculated may exceed the actual solubility of hydrogen in water under the relevant conditions and that a separate gas phase may be generated; nevertheless, the 
equation predicts the quantity of $\mathrm{H}_{2}$ per volume of water. The protolith for pseudotachylite samples 1-7 was the famous Lewisian Gneiss. These pseudotachylites probably formed at depths of four to five kilometres (Sibson, 1975). At the present day, the porosity of Lewisian gneiss is reported by geophysical surveys as $0.07 \%$ at $1 \mathrm{~km}$ depth and $0.005 \%$ at $2 \mathrm{~km}$ depth (Hall, 1987). Substituting into Equation 1 the value of the empirical coefficient $\alpha$ determined for granite by Hirose et al. (2011; 2012; these authors did not report a value for gneiss) therefore yields an estimated $\mathrm{H}_{2}$ abundance (per volume of water) of $0.2 \mathrm{~mol} \mathrm{dm}{ }^{-3}$ at $1 \mathrm{~km}^{\text {depth }}$ and $5 \mathrm{~mol} \mathrm{dm}^{-3}$ at $2 \mathrm{~km}$ depth, with still higher concentrations at greater depths. Thus, it is realistic to explain the comparable $\mathrm{H}_{2}$ values measured in our pseudotachylites (Section 3) as the product of ancient earthquakes in the Lewisian gneiss, generated mechanically and trapped in groundwater within fluid inclusions. Isotopic study of the $\mathrm{H}_{2}$ (i.e. D/H ratio) would facilitate more rigorous testing of genetic hypotheses, but may be technically challenging for such small volumes.

\subsection{Biological utility of measured hydrogen enrichments}

Hirose et al. (2011) report that seismogenic $\mathrm{H}_{2(\mathrm{aq})}$ in fault zones may attain concentrations in excess of one millimolar, which they follow Takai et al. 2006 in regarding as the lower limit for the support of lithoautotrophic microbial communities. Both thermodynamic considerations and field measurements suggest that the true requirement may be much lower. In order to be metabolically viable, archaeal methanogenesis must yield free energies of at least $-10 \mathrm{~kJ} \mathrm{~mol}^{-1}$ $\mathrm{CH}_{4}$ (Hoehler et al., 2001; Heuer et al., 2009). In deep marine sediments, it has been shown that $\mathrm{H}_{2(\mathrm{aq})}$ concentrations of only $1 \mathrm{nM}\left(10^{-9} \mathrm{~mol} \mathrm{dm}{ }^{-3}\right)$ enable methanogenic $\mathrm{CO}_{2}$ reduction to meet this criterion (Heuer et al., 2009). The steady state $\mathrm{H}_{2(\mathrm{aq})}$ concentration measured in natural hydrogen-powered ecosystems provides an upper limit for the minimum viable concentration. Lovley \& Goodwin (1988) estimate that the steady state $\mathrm{H}_{2(\mathrm{aq})}$ concentration in sediments with 
hydrogenotrophic methanogenesis or sulphate reduction should be 13 or $1 \mathrm{nM}$ respectively. More recently, $\mathrm{H}_{2}$ concentrations of $\sim 10 \mathrm{nM}$ were measured in a 200-m deep igneous aquifer supporting hydrogenotrophic methanogens (Chapelle et al., 2002). Hence, even $\mathrm{H}_{2}$ concentrations of millimolar magnitude are probably far in excess of minimum biological requirements.

If the measured fluids are indeed representative of groundwater trapped during fault motion, then they therefore support the hypothesis that fault-generated gas (from all sources) could supply energy to microbes in fracture zones. Moreover, while most fault-related $\mathrm{H}_{2}$ presumably escapes into pore and fracture waters where it could support microbial hydrogenotrophs, these results may indicate that another (no doubt far smaller) portion of it is trapped and retained by fault rocks, producing the strong $\mathrm{H}_{2}$ enrichments we observed. Once preserved in fault rocks, the trapped $\mathrm{H}_{2}$ may be subsequently liberated by reactivation of the fault, along with any newly generated gas. For example, the numerous reactivation events in the Outer Hebrides Fault Zone may have repeatedly released $\mathrm{H}_{2}$ from pseudotachylites into local groundwater (e.g. Osinski et al., 2001). Pseudotachylites are particularly vulnerable to alteration and destruction in a variety of other ways that could liberate $\mathrm{H}_{2}$ (Rabinowitz et al., 2011; Kirkpatrick and Rowe, 2013). As noted, concentrations of $\mathrm{H}_{2}$ as low as $10^{-9} \mathrm{M}$ can probably support hydrogenotrophic methanogens. Our samples liberated on average about $2 \times 10^{-11} \mathrm{~mol} \mathrm{H}_{2}$ per gram of pseudotachylite (with a range from $5 \times 10^{-13}$ to $9 \times 10^{-11}$ ); hence, the $\mathrm{H}_{2}$ contents of one gram of pseudotachylite are sufficient to stimulate methanogenesis in ten millilitres of water, at least instantaneously. The $\mathrm{CO}_{2}$ necessary for methanogenesis is also available from groundwater (and detected in our pseudotachylites; Table 2). 


\subsection{Implications for martian habitability}

It is widely recognised that the most hospitable environments for life on present-day Mars are likely to occur in the deep subsurface (e.g. Boston et al., 1992; Fisk \& Giovannoni, 1999; Westall et al., 2013; Cockell, 2014). There is good evidence that liquid water was abundant at the martian surface for long periods of geological time, and most of this water is expected to remain on Mars in the form of ground ice and sub-permafrost liquid aquifers, which potentially achieve thicknesses of up to several hundred metres (Cockell, 2014; Clifford et al., 2010). If present, these aquifers are likely to be buried, on average, $\geq 5 \mathrm{~km}$ below the surface, although local variation may be considerable (Clifford et al. 2010).

To assess whether frictionally controlled $\mathrm{H}_{2}$-generating processes on fault planes could generate biologically significant quantities of hydrogen in present-day subsurface aquifers on Mars, we adapt the model of Hirose et al. $(2011,2012)$ for the martian geological context (compaction curve, rock type and gravitational field strength).

Equation 1 yields the approximate $\mathrm{H}_{2}$ "concentration in a fault zone immediately after a seismic event as a function of porosity, dynamic friction coefficient and effective stress (Hirose et al., 2011). Both porosity and effective stress (lithostatic pressure minus fluid pore pressure) vary with depth below the martian surface. Figure 7 shows the modelled concentrations of seismogenic $\mathrm{H}_{2}$ as a function of Mars-quake depth according to the porosity-depth relationships given by Athy's formula $\left(\varphi_{\mathrm{z}}=\varphi_{0} \mathrm{e}^{-k z}\right.$ where $\varphi=$ porosity, $\varphi_{0}=$ surface porosity, $k=$ the compaction coefficient and $z=$ depth; Athy, 1930) supplied with the martian parameters of Clifford et al. (2010). Fracture porosity and cataclasis in fault zones could either increase or 
decrease bulk porosity away from this background curve. Higher porosities yield smaller concentrations because the volume of fluid into which the $\mathrm{H}_{2}$ is dispersed is greater. It is assumed that the dynamic friction coefficient is 0.25 , pore pressure is hydrostatic, and fluid does not flow away from the fault during seismic activity.

It was suggested in Section 4.2 that hydrogenotrophic communities require $\mathrm{H}_{2(\text { aq) }}$ concentrations of at least $10 \mathrm{nM}\left(10^{-8} \mathrm{~mol} \mathrm{~L}^{-1}\right)$. The modelled seismogenic $\mathrm{H}_{2}$ concentrations below a few $\mathrm{km}$ depth are five or six orders of magnitude above this threshold and therefore eminently capable of supporting life. The volume of fluids in which these high $\mathrm{H}_{2(\mathrm{aq})}$ concentrations are actually present depends on the magnitude of the seismic event as well as the availability of liquid water; if all the pores are filled with water, it is simply the product of the average displacement $D(M)$ on the fault, the surface area $\mathrm{S}(\mathrm{M})$ on which displacement occurs, and the porosity (Hirose et al., 2011). Following Hirose et al. (2011), we derive both D(M) and S(M) from the magnitude by the empirical formulae of Utsu, 2001: $\mathrm{D}(\mathrm{M})=10^{1 / 2 \mathrm{M}-3.1} ; \mathrm{S}(\mathrm{M})=10^{\mathrm{M}+2}$. Under martian conditions, if the fluids are trapped within the fault zone and all pores are filled with fluid, the groundwater volume varies from only $5.0 \mathrm{~m}^{3}$ for a magnitude- 2 event at $5 \mathrm{~km}$ depth to $3.7 \times 10^{7} \mathrm{~m}^{3}$ for a magnitude-7 event at $10 \mathrm{~km}$ depth, if porosity follows the higher curve in Figure 7 and the empirical coefficient $\alpha$ in Equation 1 is given the experimental value determined for watersaturated basalt under terrestrial air (Hirose et al., 2011).

At the present day, events of these magnitudes or greater occur somewhere on Mars on average every 34 days and every 4,500 years respectively according to the most conservative model of martian seismicity proposed by Knapmeyer et al. (2006). This model is based on a fault 
catalogue compiled from Mars Global Surveyor altimetry data; direct measurement of seismic activity on Mars awaits the arrival of the SEIS planetary seismometer to be carried on the Insight mission (Mimoun et al., 2012). Combined with the results of Hirose et al. (2011, 2012), it predicts that average annual cumulative $\mathrm{H}_{2}$ production is less than 10 tonnes over the entire planet. Hence, although seismic $\mathrm{H}_{2}$ production could sporadically fuel pockets of microbial activity on Mars, it would be highly spatially and temporally restricted to fault activity and its aftermath, with small total biomass. Nevertheless, faulting and fracturing during seismic activity on Mars (Mars-quakes and impact events) can improve subsurface habitability in at least two other ways. Firstly, permeability and potentially porosity are increased in the fracture zone, creating new habitable space and enabling fluid flow and cell transport (Sleep, 2012). Secondly, fresh rock surfaces may be brought into contact with circulating water, enabling life-supporting water-rock reactions and $\mathrm{H}_{2}$ production by radiolysis (Sleep \& Zoback, 2007). It is interesting to note that, like radiolysis, the crushing of quartz in water has also been found to produce hydroxyl radicals (e.g. Shi et al., 1988). Thus, there is a previously unrecognised possibility that pyrite is abiotically oxidised to sulphate in the vicinity of active faults, supplying another electron acceptor of key interest on Mars. Experimental work would be worthwhile to determine whether this phenomenon could generate the anomalies in the sulphate concentration of groundwater reported in association with earthquakes (e.g. Song et al., 2006; Harabaglia et al., 2008).

Mars may have had something more like a plate tectonic regime in the distant past (e.g. Yin, 2012). Numerous large faults are exposed at the martian surface, which is also heavily fractured and cratered by billions of years of impacts. It has been proposed that craters could have provided local refugia for microbial life on Mars (and early Earth) by increasing the temperature 
and porosity of the target region, enabling hydrothermal circulation over geological timescales (Cockell, 2004). One might speculate that these conditions could also have stimulated the origin of life itself on either planet, providing "crucibles" in which the components necessary for the origin of life evolved through a slow cooling curve, favouring a sequence of prebiotic reactions in a long-lived hydrothermal system (Cockell, 2004; 2006). Our results suggest that a supply of seismogenic $\mathrm{H}_{2}$ may have contributed to both the habitability and prebiotic chemical evolution of these systems.

\section{Conclusions}

This study has shown that fault rocks contain elevated quantities of hydrogen gas. The hydrogen concentrations implied by the measured $\mathrm{H}_{2}$ and $\mathrm{H}_{2} \mathrm{O}$ contents are sufficient to support hydrogenotrophic microorganisms, with implications for the habitability of fault zones, if the fluids measured represent trapped fault-zone porewaters. Although fluids derived from other sources may also be present, the enrichment in the fault rocks compared to controls is consistent with faulting-related $\mathrm{H}_{2}$ production, for which several possible mechanisms have been described. Extending to Mars the empirical model of Hirose et al. (2011) for frictionally controlled $\mathrm{H}_{2}$ production on fault planes, we find that the low level of martian seismicity is sufficient by itself to support spatiotemporally limited hydrogenotrophy in the subsurface. These considerations together with many others suggest that fault rocks or fault-related mineral vein networks deserve consideration as a target for biosignature sampling by future Mars missions.

\section{Acknowledgments}

SM thanks the STFC for a PhD studentship and the NASA Astrobiology Institute for additional funding (NNAI13AA90A; Foundations of Complex Life, Evolution, Preservation and Detection 
on Earth and Beyond). Alison Wright, Roger Gibson and Edward Lynch are thanked for contributing samples. We thank three anonymous reviewers for their insightful comments.

\section{Author Disclosure Statement}

No competing financial interests exist. 


\section{REFERENCES}

Allison, I., May, F., and Strachan, R. A. (1988) An excursion guide to the Moine geology of the Scottish Highlands. Scottish Academic Press, Edinburgh, UK, 270 pp.

Anders, M. H., Laubach, S. E., \& Scholz, C. H. (2014) Microfractures: a Review. Journal of Structural Geology 69, 377-394.

Athy, L. F. (1930) Density, porosity, and compaction of sedimentary rocks. AAPG Bulletin $14,1-24$.

Barrow, G., and Flett, J. S. (1906) The geology of the Isles of Scilly. HM Stationery Office, London, $78 \mathrm{pp}$.

Blair, C. C., D’Hondt, S., Spivack, A. J., and Kingsley, R. H. (2007) Radiolytic hydrogen and microbial respiration in subsurface sediments. Astrobiology 7:951-970.

Blamey, N. J. F. (2012) Composition and evolution of crustal, geothermal and hydrothermal fluids interpreted using quantitative fluid inclusion gas analysis. Journal of Geochemical Exploration 116:17-27.

Blamey, N. J. F., Parnell, J., McMahon, S., Mark, D., Tomkinson, T., Lee, M. R., Shivak, J., Izawa, M. R. M., Banerjee, N. R., and Flemming, R. (2015) Evidence for methane in Martian meteorites. Nature Communications 6:7399.

Boullier, A-M., Ohtani, T., Fujimoto, K., Ito, H., \& Dubois M. (2001) Fluid inclusions in pseudotachylytes from the Nojima fault, Japan. Journal of Geophysical Research 106:2196521977.

Boston, P. J., Ivanov, M. V., and McKay, C. P. (1992) On the possibility of chemosynthetic ecosystems in subsurface habitats on Mars. Icarus 95:300-308.

Chapelle, F. H., O’Neill, K., Bradley, P. M., Methé, B. A., Ciufo, S. A., Knobel, L. L., and Lovley, D. R. (2002) A hydrogen-based subsurface microbial community dominated by methanogens. Nature 415:312-315.

Chen, Y., Clark, A. H., Farrar, E., Wasteneys, H. A. H. P., Hodgson, M. J., and Bromley, A. V. (1993) Diachronous and independent histories of plutonism and mineralization in the Cornubian Batholith, southwest England. Journal of the Geological Society 150:1183-1191.

Clifford, S. M., Lasue, J., Heggy, E., Boisson, J., McGovern, P., and Max, M. D. (2010) Depth of the Martian cryosphere: Revised estimates and implications for the existence and detection of subpermafrost groundwater. Journal of Geophysical Research 115:E07001.

Cockell, C. S. (2004) Impact-shocked rocks-insights into archean and extraterrestrial microbial habitats (and sites for prebiotic chemistry?). Advances in Space Research 33:1231-1235.

Cockell, C. S. (2006) The origin and emergence of life under impact bombardment. Philosophical Transactions of the Royal Society B: Biological Sciences 361:1845-1856. 
Cockell, C. S. (2014) Trajectories of Martian Habitability. Astrobiology 14:182-203

Fisk, M. R., and Giovannoni, S. J. (1999) Sources of nutrients and energy for a deep biosphere on Mars. Journal of Geophysical Research 104:11805-11815.

Freund, F., Dickinson, J. T., and Cash, M. (2002) Hydrogen in Rocks: An Energy Source for Deep Microbial Communities. Astrobiology 2:83-92.

Goodenough, K. M., Millar, I., Strachan, R. A., Krabbendam, M., and Evans, J. A. (2011) Timing of regional deformation and development of the Moine Thrust Zone in the Scottish Caledonides: constraints from the U-Pb geochronology of alkaline intrusions. Journal of the Geological Society 168:99-114.

Hall, J. (1987) Physical properties of Lewisian rocks: Implications for deep crustal structure. Geological Society, London, Special Publications 27:185-192.

Harabaglia, P., Mongelli, G., and Paternoster, M. (2008) A Geochemical Survey of the Telese Hydrothermal Spring, Southern Italy: Sulfate Anomalies Induced by Crustal Deformation. Environmental Geosciences 9:89-101.

Heuer, V. B., Pohlman, J. W., Torres, M. E., Elvert, M., and Hinrichs, K. U. (2009) The stable carbon isotope biogeochemistry of acetate and other dissolved carbon species in deep subseafloor sediments at the northern Cascadia Margin. Geochimica et Cosmochimica Acta 73: $3323-3336$.

Hirose, T., Kawagucci, S., and Suzuki, K. (2011) Mechanoradical $\mathrm{H}_{2}$ generation during simulated faulting: Implications for an earthquake-driven subsurface biosphere. Geophysical Research Letters 38:L17303.

Hirose, T., Kawagucci, S., and Suzuki, K. (2012) Correction to "Mechanoradical H2 generation during simulated faulting:Implications for an earthquake-driven subsurface biosphere". Geophysical Research Letters 39:L23304.

Hoehler, T. M., Alperin, M. J., Albert, D. B., and Martens, C. S. (2001) Apparent minimum free energy requirements for methanogenic Archaea and sulphate-reducing bacteria in an anoxic marine sediment. FEMS Microbiology Ecology 38:33-41.

Kirkpatrick, J. D., and Rowe, C. D. (2013) Disappearing ink: How pseudotachylytes are lost from the rock record. Journal of Structural Geology 52:183-198.

Kita, I., Matsuo, S., and Wakita, H. (1982) $\mathrm{H}_{2}$ generation by reaction between $\mathrm{H}_{2} \mathrm{O}$ and crushed rock: An experimental study on $\mathrm{H}_{2}$ degassing from the active fault zone. Journal of Geophysical Research 87:10,789-10,795.

Knapmeyer, M., Oberst, J., Hauber, E., Wahlisch, M., Deuchler, C., and Wagner, R. (2006) Working models for spatial distribution and level of Mars' seismicity. Journal of Geophysical Research 111:E11006. 
Krabbendam, M., and Leslie, A. G. (2010) Lateral variations and linkages in thrust geometry: the Traligill Transverse Zone, Assynt Culmination, Moine Thrust Belt, NW Scotland. Geological Society, London, Special Publications 335:335-357.

Kral, T. A., Brink, K. M., Miller, S. L., and McKay, C. P. (1998) Hydrogen consumption by methanogens on the early Earth. Origins of Life and Evolution of the Biosphere 28:311-319.

Lafrance, B., and Kamber, B. S. (2010) Geochemical and microstructural evidence for in situ formation of pseudotachylitic Sudbury breccia by shock-induced compression and cataclasis. Precambrian Research 180, 237-250.

Lane, N., and Martin, W. F., 2012. The Origin of Membrane Bioenergetics. Cell 151:14061416.

Lespinasse, M., and Cathelineau, M. (1990) Fluid percolations in a fault zone: a study of fluid inclusion planes in the St Sylvestre granite, northwest Massif Central, France. Tectonophysics 184:173-187.

Lin, L., Hall, J., Lippmann-Pipke, J., Ward, J. A., Sherwood Lollar, B., DeFlaun, M., Rothmel, R., Moser, D., Gihring, T. M., and Mislowack, B. (2005). Radiolytic H2 in continental crust: nuclear power for deep subsurface microbial communities. Geochemistry, Geophysics, Geosystems 6, Q07003.

Lloyd, G. E. (2000) Grain boundary contact effects during faulting of quartzite: an SEM/EBSD analysis. Journal of Structural Geology 22:1675-1693.

Lovley, D. R., and Goodwin, S. (1988) Hydrogen concentrations as an indicator of the predominant terminal electron-accepting reactions in aquatic sediments. Geochimica et Cosmochimica Acta 52:2993-3003.

Macloughlin, J. F., and Spray, J. G. (1992) Frictional melting processes and products in geological materials: introduction and discussion. Tectonophysics 204:197-206.

McCollom, T. M. (1999) Methanogenesis as a potential source of chemical energy for primary biomass production by autotrophic organisms in hydrothermal systems on Europa. Journal of Geophysical Research 104:30729-30742.

McMahon, S., Parnell, J., and Blamey, N. J. F. (2012) Sampling methane in hydrothermal minerals on Earth and Mars. International Journal of Astrobiology 11:163-167.

McMahon, S., Parnell, J., Ponicka, J., Hole, M. and Boyce, A. (2013) The habitability of vesicles in Martian basalt. Astronomy \& Geophysics 54:1.17-1.21.

Mendum, J.R., Barber, A.J., Butler, R.W., Flinn, D., Goodenough, K.M., Krabbendam, M., Park, R.G., and Stewart, A.D. (2009) Lewisian, Torridonian and Moine rocks of Scotland. Geological Conservation Review Series 34, Joint Nature Conservation Committee, Peterborough.

Michalski, J. R., Cuadros, J., Niles, P. B., Parnell, J., Rogers, A. D., and Wright, S. P. (2013) Groundwater activity on Mars and implications for a deep biosphere. Nature Geoscience 6:133138. 
Mimoun, D., Lognonne, P.., Banerdt, W. B., Hurst, K., Deraucourt, S., Gagnepain-Beyneix, J., Pike, T., Calcutt, S., Bierwirth, M., Roll, R., Zweifel, P., Mance, D., Robert, O., Nebut, T., Tillier, S., Gabsi, T., Laudet, Ph., Kerjean, L., Perez, R., Giardini, D., Christenssen, U., Garcia, R., \& the SEIS Team, 2012. The InSight SEIS Mission. Lunar and Planetary Science Conference XLIII. Abstract 1493.

Moore, J. N., Norman, D. I., and Kennedy, B. M. (2001) Fluid inclusion gas compositions from an active magmatic-hydrothermal system: a case study of The Geysers geothermal field, USA. Chemical Geology 173:3-30.

Nixon, S. L., Cousins, C. R., and Cockell, C. S. (2013) Plausible microbial metabolisms on Mars. Astronomy \& Geophysics 54:1.13-1.16.

Norman, D. I., and Moore, J. N. (1997) Gaseous species in fluid inclusions: a fluid tracer and indicator of fluid processes. In: ECROFI (European Current Research on Fluid Inclusions) XIV, pp. 243-244.

Onstott, T. C., McGown, D., Kessler, J., Lollar, B. S., Lehmann, K. K., and Clifford, S. M. (2006) Martian CH4: sources, flux, and detection. Astrobiology 6:377-395.

Osinski, G. R., Alsop, G. I., and Oliver, G. J. H. (2001) Extensional tectonics of the Outer Hebrides Fault Zone, South Uist, northwest Scotland. Geological Magazine 138:325-344.

Parnell, J., Bowden, S., Lindgren, P., Burchell, M., Milner, D., Price, M., Baldwin, E. C., and Crawford, I. A. (2010) The preservation of fossil biomarkers during meteorite impact events: Experimental evidence from biomarker-rich projectiles and target rocks. Meteoritics \& Planetary Science 45:1340-1358.

Parry, W. T., and Blamey, N. J. F. (2010) Fault fluid composition from fluid inclusion measurements, Laramide age Uinta thrust fault, Utah. Chemical Geology 278:105-119.

Rabinowitz, H., Skemer, P. A., Mitchell, T. M., and Di Toro, G. (2011) Experimental reactivation of pseudotachylite-bearing faulted rocks. In: AGU Fall Meeting Abstracts 1, 2341.

Riller, U., and Schwerdtner, W. M. (1997) Mid-crustal deformation at the southern flank of the Sudbury Basin, central Ontario, Canada. Geological Society of America Bulletin 109:841-854.

Riller, U., Lieger, D., Gibson, R. L., Grieve, R. A., and Stöffler, D. (2010) Origin of large volume pseudotachylite in terrestrial impact structures. Geology 38:619-622.

Schulte, M., Blake, D., Hoehler, T., and McCollum, T. (2006) Serpentinization and its implications for life on the early Earth and Mars. Astrobiology 6:364-376.

Sherlock, S. C., Jones, K. A., and Park, R. G. (2008) Grenville-age pseudotachylite in the Lewisian: laser probe 40Ar/39Ar ages from the Gairloch region of Scotland (UK). Journal of the Geological Society 165:73-83.

Sherwood Lollar, B., Volgesonger, K., Lin, L.-H., Lacrampe-Coulombe, G., Telling, J., Abrajano, T. A., Onstott, T. C. and Pratt, L. M. (2007) Hydrogeologic controls on episodic $\mathrm{H}_{2}$ 
release from Precambrian Fractured Rocks-Energy for Deep Subsurface Life on Earth and Mars. Astrobiology 7:971-986.

Sherwood Lollar, B., Onstott, T. C., Lacrampe-Coulombe, G., and Ballentine, C. J. (2014) The contribution of the Precambrian continental lithosphere to global $\mathrm{H}_{2}$ production. Nature 7351:379-382.

Sibson, R. H. (1975) Generation of pseudotachylyte by ancient seismic faulting. Geophys. $R$. Astr. Soc. 43:775-794.

Sleep, N. H. (2012) Maintenance of permeable habitable subsurface environments by earthquakes and tidal stresses. International Journal of Astrobiology 11:257-268.

Sleep, N. H., Bird, D. K., and Pope, E. C. (2011) Serpentinite and the dawn of life.

Philosophical Transactions of the Royal Society B: Biological Sciences 366:2857-2869.

Sleep, N. H. and Zoback, M. D. (2007) Did earthquakes keep the early crust habitable? Astrobiology 7:1023-1032.

Song, S. R., Ku, W. Y., Chen, Y. L., Liu, C. M., Chen, H. F., Chan, P. S., Chen, Y. G., Yang, T. F., Chen, C. H., Liu, T. K., and Lee, M. (2006) Hydrogeochemical Anomalies in the Springs of the Chiayi Area in West-central Taiwan as Possible Precursors to Earthquakes. Pure and Applied Geophysics 163:675-691.

Stevens, T. O., and McKinley, J. P. (1995) Lithoautotrophic microbial ecosystems in deep basalt aquifers. Science 270:450-455.

Takai, K., Nakamura, K., Suzuki, K., Inagaki, F., Nealson, K. H., and Kumagai, H. (2006) Ultramafics-Hydrothermalism-Hydrogenesis-HyperSLiME (UltraH3) linkage: a key insight into early microbial ecosystem in the Archean deep-sea hydrothermal systems. Paleontological research 10:269-282.

Utsu, T. (2001) Seismology. Kyoritsu, Tokyo.

Wakita, H., Nakamra, Y., Kita, I., Fujii, N., and Notsu, K. (1980) Hydrogen release: New indicator of fault activity. Science 210:188-190.

Wenk, H. R. (1978) Are pseudotachylites products of fracture or fusion? Geology 6:507-511.

Westall, F., Loizeau, D., Foucher, F., Bost, N., Bertrand, M., Vago, J., and Kminek, G. (2013) Habitability on Mars from a Microbial Point of View. Astrobiology 13:887-897.

Wiersberg, T., and Erzinger, J. (2008) On the origin and spatial distribution of gas at seismogenic depths of the San Andreas Fault from drill mud gas analysis. Applied Geochemistry 23:1675-1690.

Yin, A. (2012) Structural analysis of the Valles Marineris fault zone: Possible evidence for largescale strike-slip faulting on Mars. Lithosphere 4:286-330. 


\section{TABLE 1}

Host rock / Sample type

Gneiss

Pseudotachylite

"

"r

r

"r

"

Country rock

Granite

Pseudotachylite

"

Country rock

"

Granite

Pseudotachylite

Country rock

Gneiss

Pseudotachylite

\section{Quartzite}

Pseudotachylite

\section{Quartzite}

Cataclasite

"l

"l

"

Country rock

"

"l

"

Quartzite

Country rock
Location / Locality

Sample \#

Outer Hebrides, Scotland, UK

Cleat, Barra

Barra Quarry, Barra

1

Allasdale Beach, Barra

2

Castlebay Pier, Barra

4

Druim Reallasger Quarry, North Uist 5

Market Stance, South Uist

6

North Uist

7

\section{Near Loch Tollie, Northwest Scotland, UK}

West locality

8,9

East locality

10

West locality

11,12

East locality

13

Isles of Scilly, UK

St. Agnes Island

14-17

St Agnes Island

$18-19$

Sudbury Crater, Canada

Creighton Pluton, near Sudbury

20

Vredefort Crater, South Africa

Parys

West Scotland, UK

Achiltibuie

22

Skiag Bridge

23

Conival, Inchnadamph

24

Corry Bridge

25

Coulags, Glen Carron

26

Skiag Bridge

27

Ben More

28

Ord, Skye

29

Northern Sweden

Kiruna

30 


\section{TABLE 2}

Location / Locality

Outer Hebrides, Scotland, UK

$\begin{array}{lllll}\text { Cleat, Barra } & 1.7 \times 10^{-1} & 9.2 \times 10^{1} & 2.9 \times 10^{-1} & 6.9 \times 10^{0} \\ \text { Barra Quarry, Barra } & 1.1 \times 10^{0} & 1.0 \times 10^{1} & 2.0 \times 10^{0} & 8.6 \times 10^{1} \\ \text { Allasdale Beach, Barra } & 1.3 \times 10^{-1} & 6.7 \times 10^{1} & 4.5 \times 10^{-1} & 3.3 \times 10^{1} \\ \text { Castlebay Pier, Barra } & 1.7 \times 10^{-1} & 9.9 \times 10^{1} & 1.3 \times 10^{-1} & 4.4 \times 10^{-1} \\ \text { Druim Reallasger Quarry, North Uist } & 1.2 \times 10^{0} & 7.8 \times 10^{1} & 7.2 \times 10^{0} & 1.2 \times 10^{1} \\ \text { Market Stance, South Uist } & 1.4 \times 10^{0} & 8.7 \times 10^{1} & 1.6 \times 10^{0} & 8.6 \times 10^{0} \\ \text { North Uist (control) } & 9.3 \times 10^{-2} & 9.7 \times 10^{1} & 1.5 \times 10^{0} & 4.2 \times 10^{-1}\end{array}$

Near Loch Tollie, Northwest

Scotland, UK

West locality

East locality

West locality (control)

East locality (control)

\section{Isles of Scilly, UK}

St. Agnes Island

St. Agnes Island (control)
$\% \mathrm{H}_{2}$
$\% \mathrm{H}_{2} \mathrm{O}$

$\% \mathrm{~N}_{2}$

$\% \mathrm{CO}_{2}$

$\begin{array}{llll}4.8 \times 10^{-1} & 9.9 \times 10^{1} & 9.6 \times 10^{-2} & 3.7 \times 10^{-1} \\ 3.4 \times 10^{-2} & 1.0 \times 10^{2} & 1.9 \times 10^{-1} & 1.5 \times 10^{-1} \\ 2.2 \times 10^{0} & 9.7 \times 10^{1} & 5.3 \times 10^{-1} & 4.3 \times 10^{-1} \\ 1.6 \times 10^{0} & 9.8 \times 10^{1} & 4.2 \times 10^{-1} & 1.3 \times 10^{-1} \\ 1.8 \times 10^{-2} & 9.9 \times 10^{1} & 2.3 \times 10^{-1} & 1.7 \times 10^{-1} \\ 7.3 \times 10^{-2} & 1.0 \times 10^{2} & 2.7 \times 10^{-1} & 4.9 \times 10^{-2}\end{array}$

\section{Sudbury Crater, Canada}

Creighton Pluton, near Sudbury

\section{Vredefort Crater, South Africa}

Parys

West Scotland, UK

Achiltibuie

Skiag Bridge

Conival, Inchnadamph

Corry Bridge

Coulags, Glen Carron (control)

Skiag Bridge (control)

Benmore Track (control)

Ord, Skye (control)

$\begin{array}{llll}1.1 \times 10^{1} & 7.5 \times 10^{1} & 8.3 \times 10^{0} & 4.0 \times 10^{0} \\ 1.7 \times 10^{0} & 9.2 \times 10^{1} & 2.4 \times 10^{0} & 3.0 \times 10^{0} \\ 6.3 \times 10^{-3} & 9.7 \times 10^{1} & 1.1 \times 10^{0} & 1.8 \times 10^{0} \\ 8.3 \times 10^{-2} & 9.8 \times 10^{1} & 8.3 \times 10^{-1} & 4.4 \times 10^{-1}\end{array}$

$2.0 \times 10^{0}$

$9.6 \times 10^{1}$

$1.6 \times 10^{0}$

$7.7 \times 10^{-2}$

Northern Sweden

Kiruna (control)

$\begin{array}{llll}1.4 \times 10^{-1} & 9.7 \times 10^{1} & 3.1 \times 10^{-1} & 2.4 \times 10^{0} \\ 8.8 \times 10^{-2} & 9.1 \times 10^{1} & 5.8 \times 10^{-1} & 8.2 \times 10^{0} \\ 5.7 \times 10^{-2} & 9.5 \times 10^{1} & 3.3 \times 10^{-1} & 4.6 \times 10^{0} \\ 1.1 \times 10^{0} & 9.7 \times 10^{1} & 4.0 \times 10^{-1} & 1.0 \times 10^{0} \\ 6.0 \times 10^{-2} & 9.4 \times 10^{1} & 5.0 \times 10^{-1} & 5.0 \times 10^{0} \\ 8.8 \times 10^{-2} & 9.1 \times 10^{1} & 5.8 \times 10^{-1} & 8.2 \times 10^{0} \\ 1.2 \times 10^{-2} & 9.4 \times 10^{1} & 1.9 \times 10^{-1} & 5.3 \times 10^{0} \\ 4.7 \times 10^{-3} & 9.8 \times 10^{1} & 1.4 \times 10^{-1} & 1.8 \times 10^{0}\end{array}$

$1.2 \times 10^{-2}$

$8.9 \times 10^{1}$

$5.2 \times 10^{-1}$

$1.1 \times 10^{1}$ 


\section{TABLE CAPTIONS}

\section{TABLE 1}

Fault-rock and control samples used in hydrogen measurements. Samples included (a) gneiss- and granited-hosted pseudotachylites, (b) gneiss and granite controls for the pseudotachlyites, (c) quartzite-hosted cataclasites, and (d) quartzite controls for the cataclasites. All pseudotachylite host rocks are Precambrian except for those from the Scilly Isles granite, which are about 290 Ma old (Chen et al., 1993). All cataclasites and quartzite controls are Cambrian except for the Palaeoproterozoic control from Kiruna, Sweden. Figure 1, 2, and 4 present the sample localities in context.

\section{TABLE 2}

Results of CFS analysis of major fluids in fault-rock and control samples. Each row represents the average of several fluid bursts released by one sample. 


\section{FIGURE CAPTIONS}

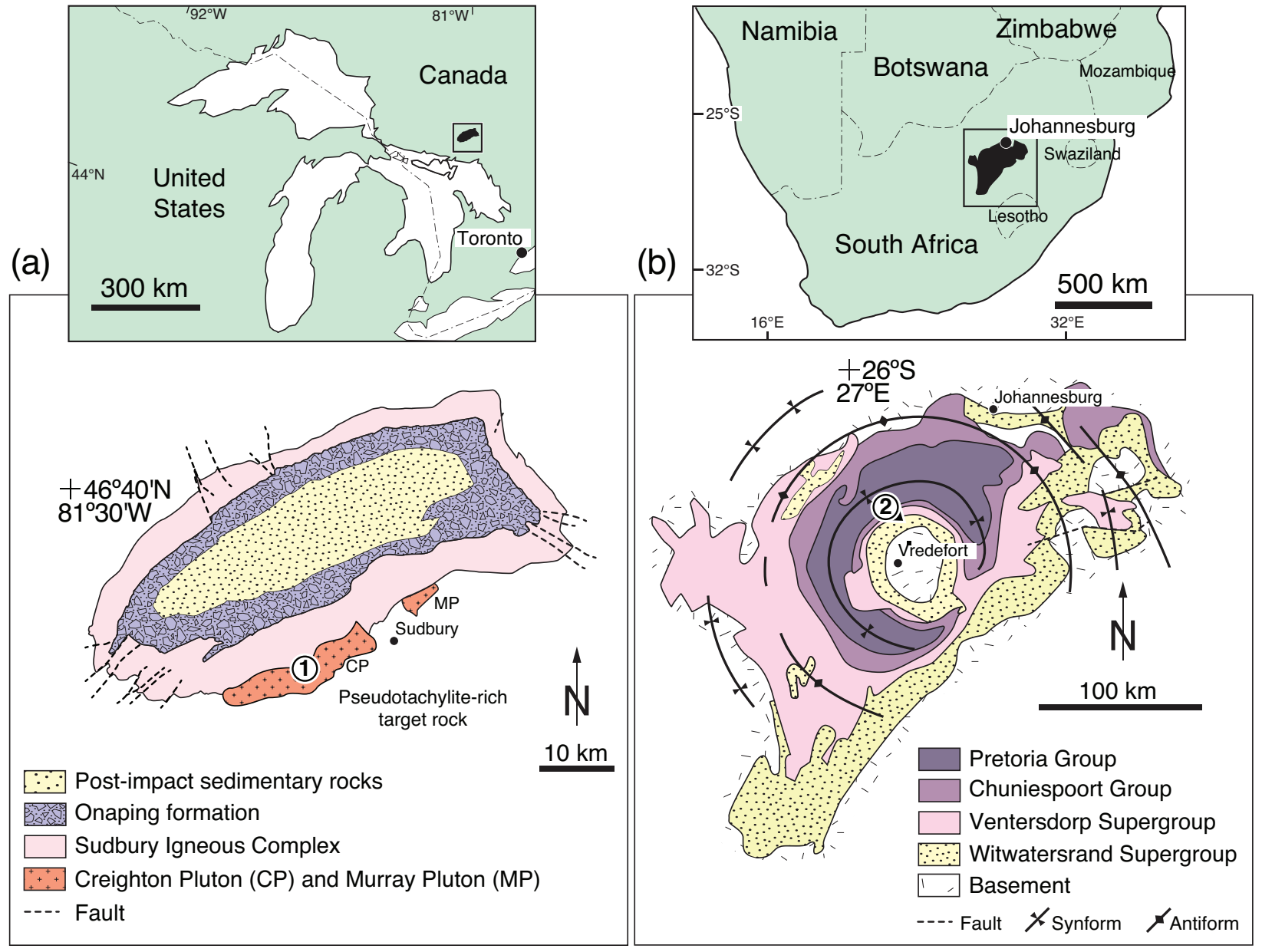

\section{FIGURE 1}

Sudbury (a) and Vredefort (b) impact structures: simplified geological maps and geographic context. In (a), (1) marks the location of Sample \#1. MP = Murray Pluton; CP = Creighton Pluton. In (b), which indicates only pre-Karoo Supergroup exposure, (2) marks the location of Sample \#2. Adapted from Riller et al. (2010), with details from Riller \& Schwertdner (1997). 


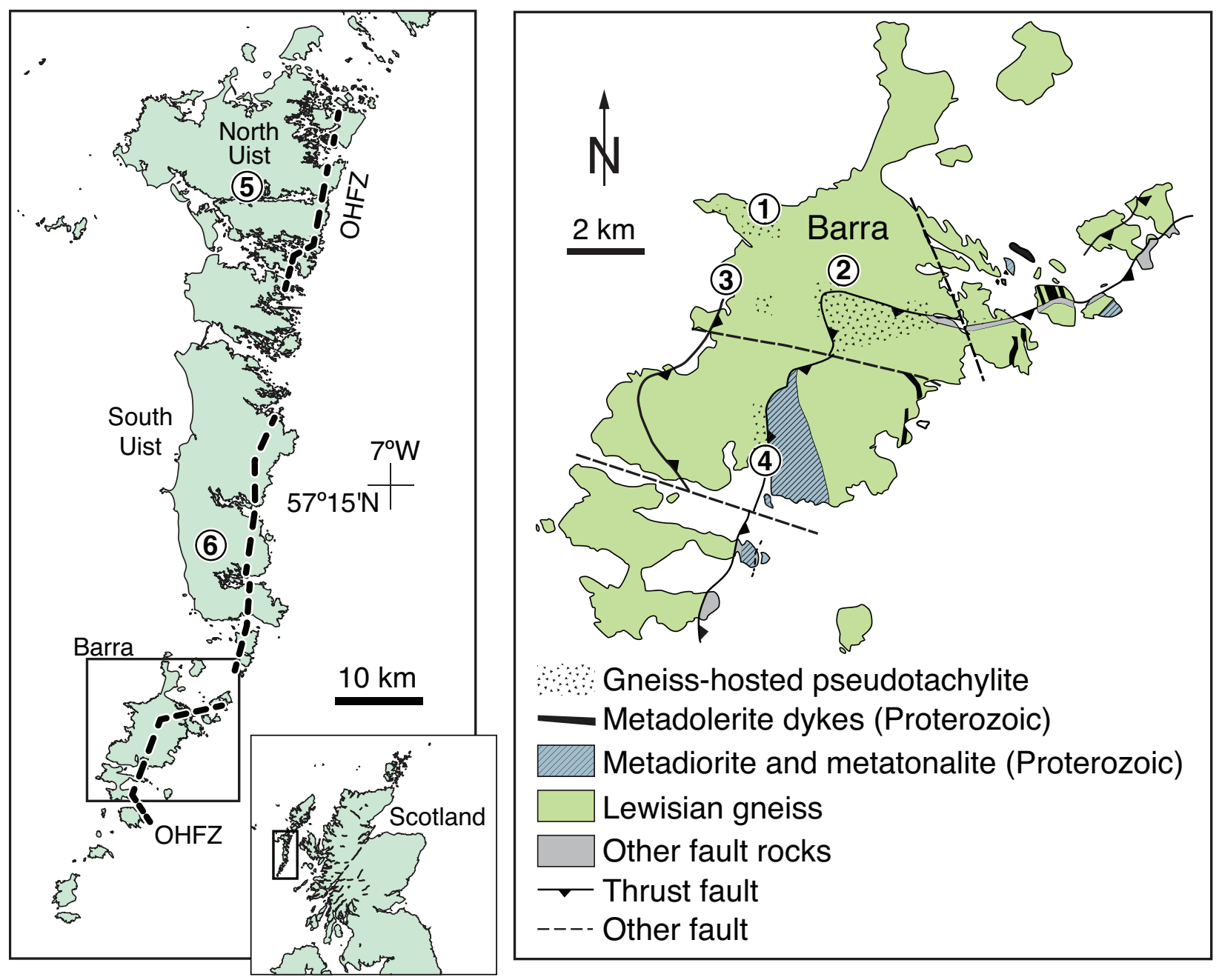

FIGURE 2

Figure 2: Pseudotachylite localities in the Outer Hebrides, and geological context on Barra. OHFZ = Outer Hebrides Fault Zone. Adapted from Osinski et al. (2001) and Mendum et al. (2009). See Table 1 for key to sample localities. 


\section{A}
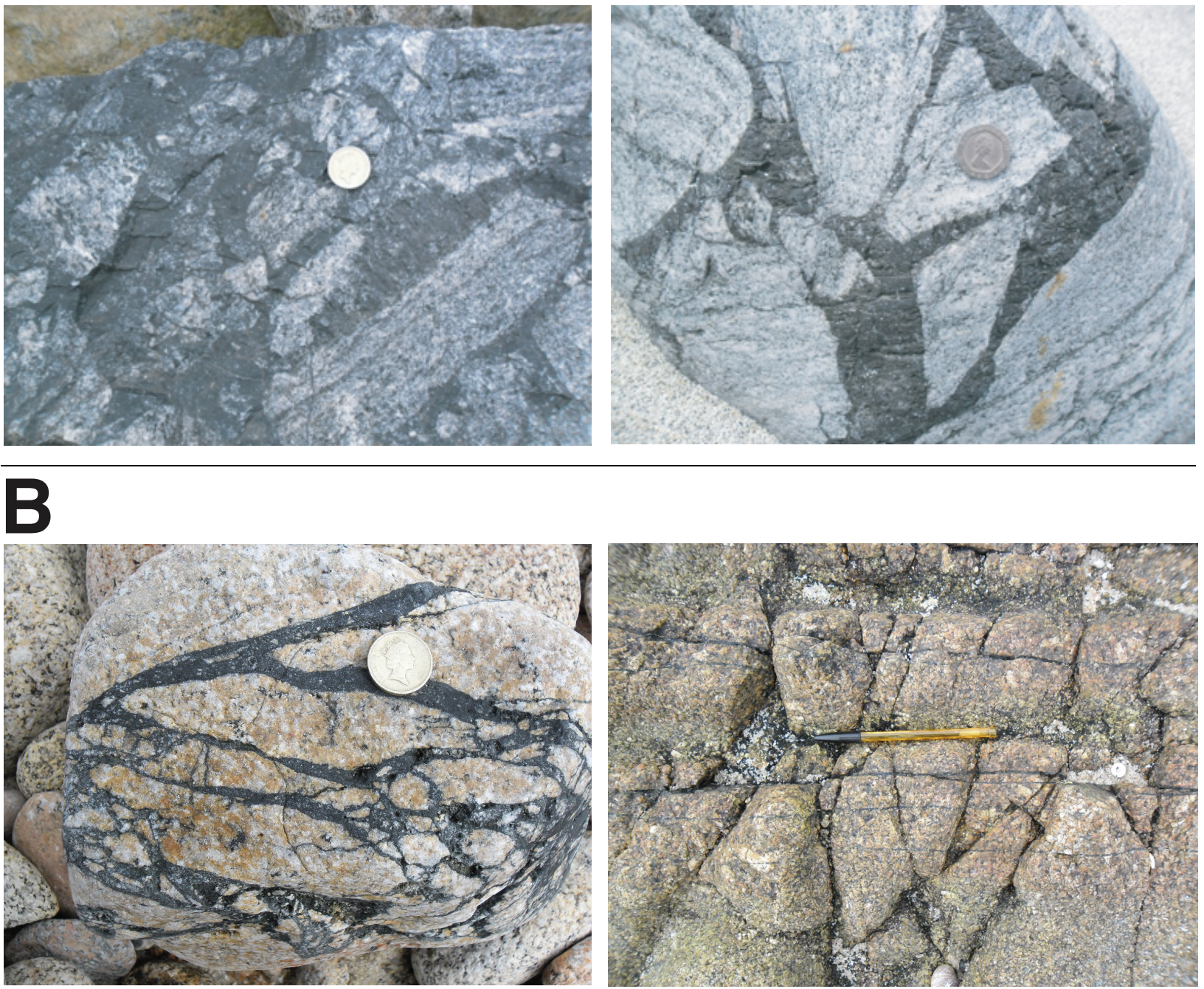

\section{FIGURE 3}

Pseudotachylites from the British Isles. (A) Examples on the beaches of Barra, Outer

Hebrides, UK. Pseudotachylites appear as the dark-coloured matrix between angular gneiss clasts. (B) Examples on the beaches of St. Agnes Island, Scilly Isles, UK. On the left, pseudotachylites appear as the dark-coloured matrix between eroded granite clasts. On the right, pseudotachylites occur in situ as thin dark veins through the granite (left to right). Coins on all images are about $20 \mathrm{~mm}$ across. 


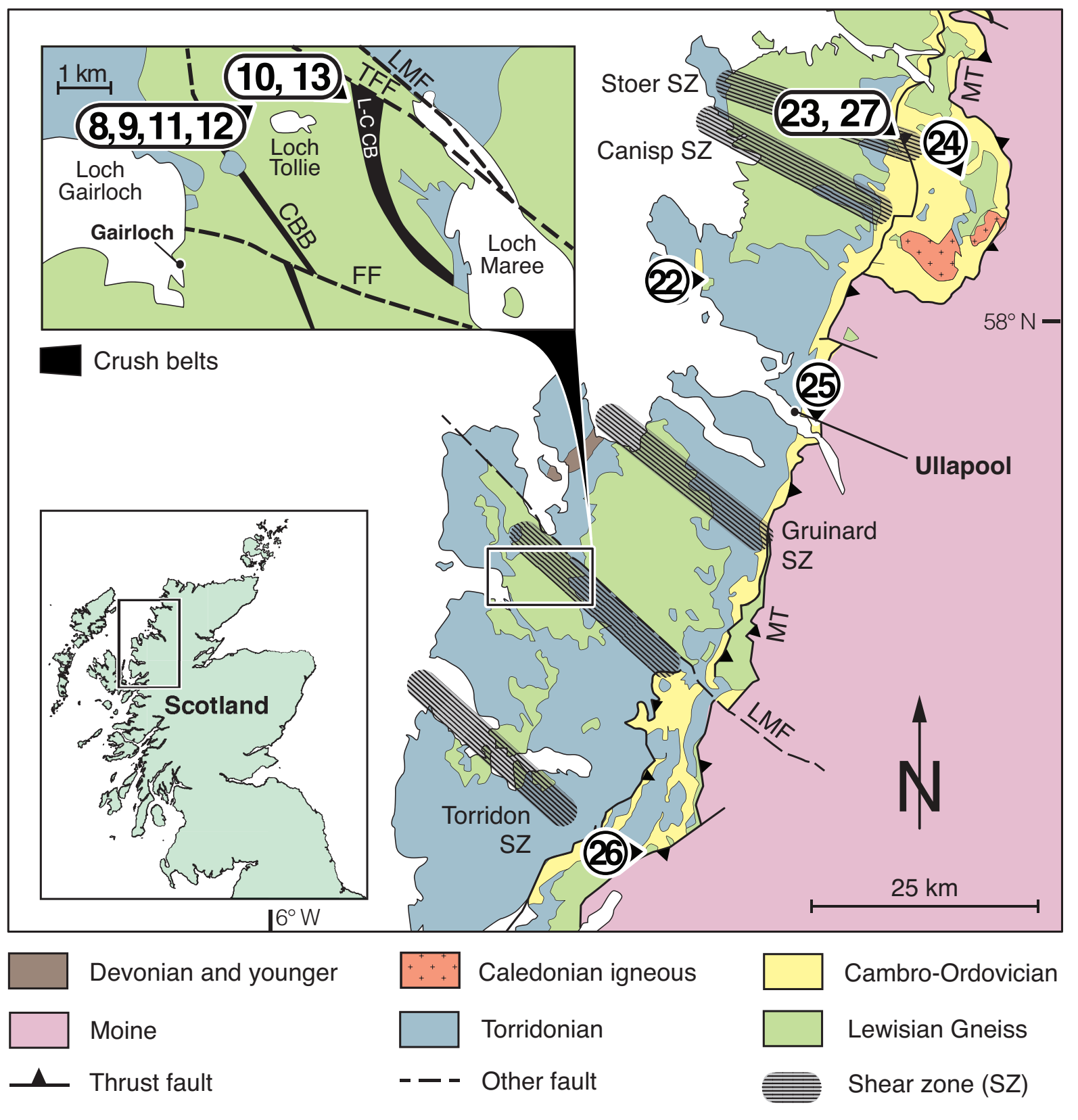

\section{FIGURE 4}

Sample localities in the Moine Thrust Belt, Northwest Highlands. Figure adapted from Krabbendam \& Leslie (2010), with inset showing Gairloch region adapted from Sherlock et al. (2008). $\mathrm{MT}=$ Moine Thrust; $\mathrm{LC}=$ Langwell Culmination; $\mathrm{DC}=$ Dundonell Culmination; $\mathrm{FH}=$ Faraid Head; SZ = Shear zone. Details east of the Moine Thrust are not shown. LMF $=$ Loch 
Maree Fault; TFF = Tollie Farm fault; L-C CB = Leth-chreige crush belt; TA = Tollie antiform; $\mathrm{CBB}=$ Creag Bahn belt; FF $=$ Flowerdale fault. See Table 1 for key to sample localities. 


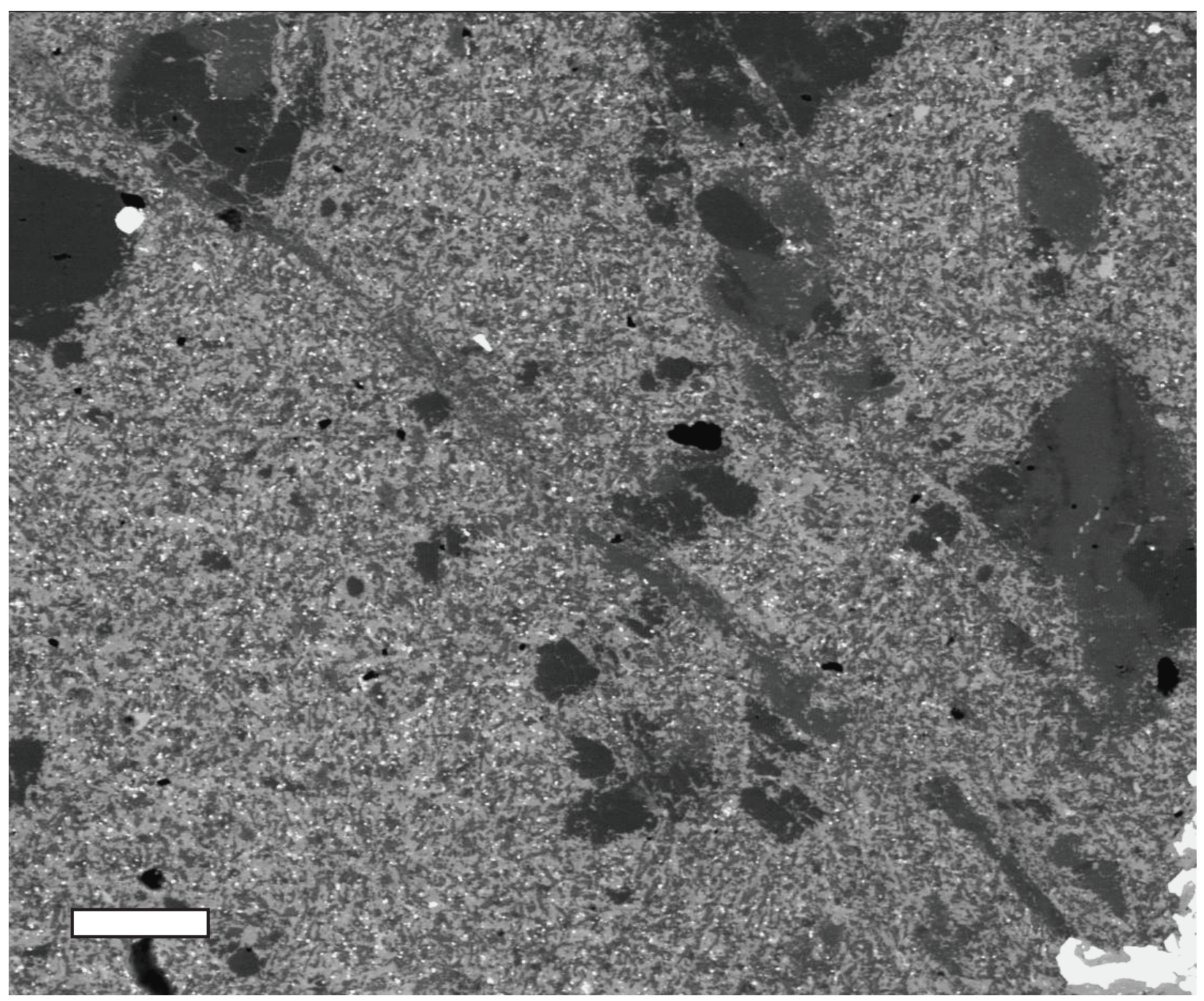

FIGURE 5

Scanning electron microscope image showing polished thin section of pseudotachylite from

Loch Tollie in Northwest Scotland. Scale bar $=100 \mu \mathrm{m}$. Healed microfractures run from the upper left to the lower right of the field of view. Note large fractured and comminuted grains of quartz and feldspar suspended in the glassy groundmass. White areas (e.g. lower right) are pyrite; black grains are iron oxides. 

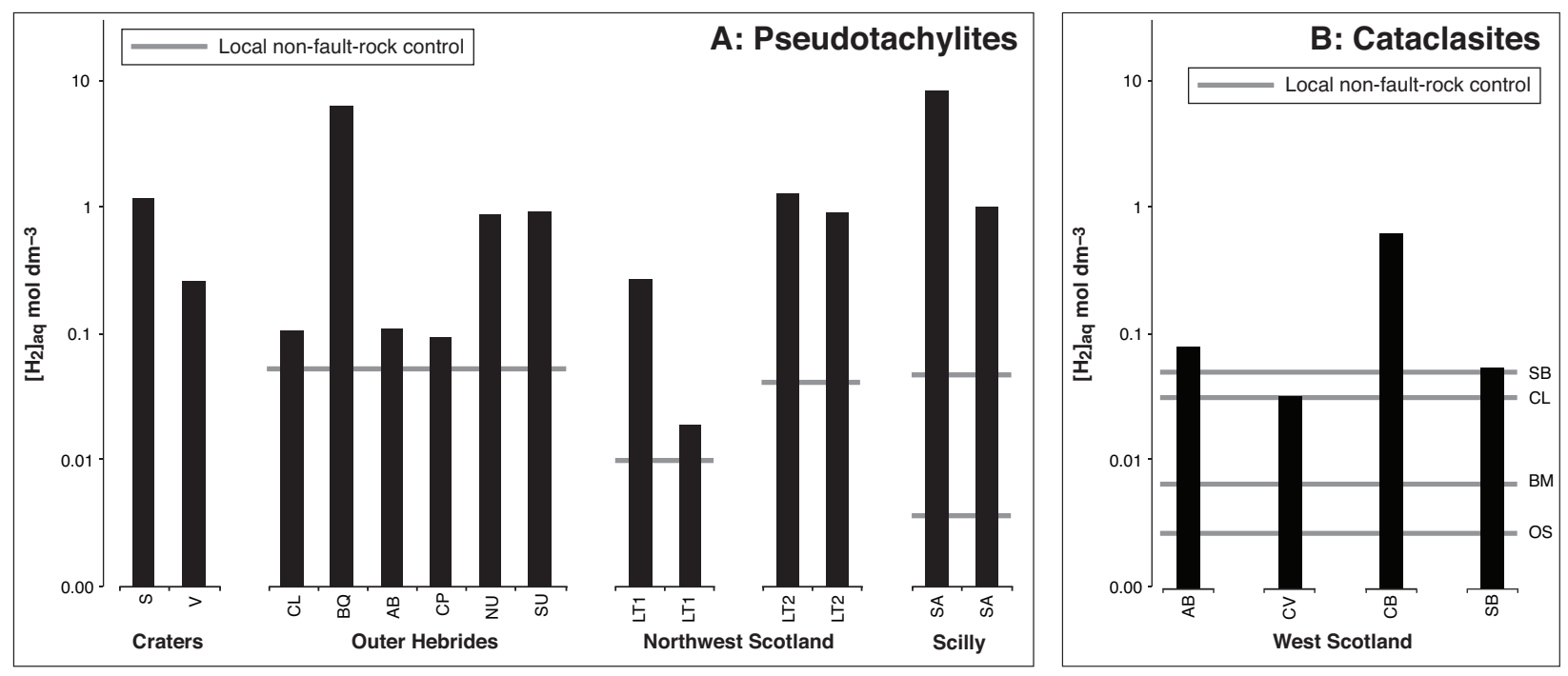

\section{FIGURE 6}

$\mathrm{H}_{2}$ in pseudotachylites (A), cataclasites (B), and country rock control samples as reconstructed aqueous concentrations $\left(\mathbf{m o l} \mathbf{d m}^{-3}\right)$. Note $\log$ axis. Craters: $\mathrm{S}=$ Sudbury, $\mathrm{V}=$ Vredefort. Outer Hebrides: $\mathrm{CL}=$ Cleat, Barra; $\mathrm{BQ}=$ Barra Quarry; $\mathrm{AB}=$ Allasdale Beach, Barra; CP = Castlebay Pier, Barra; NU = North Uist; SU = South Uist. Northwest Scotland: LT1 $=$ Loch Tollie West; LT2 = Loch Tollie East. Scilly: SA = St Agnes Island. Cataclasites: AB = Achiltibuie; $\mathrm{CV}=$ Conival; $\mathrm{CB}=$ Corry Bridge; $\mathrm{SB}=$ Skiag Bridge; $\mathrm{CL}=$ Coulags; $\mathrm{BM}=\mathrm{Ben}$ More; OS = Ord, Skye. 
(a) Compaction curve

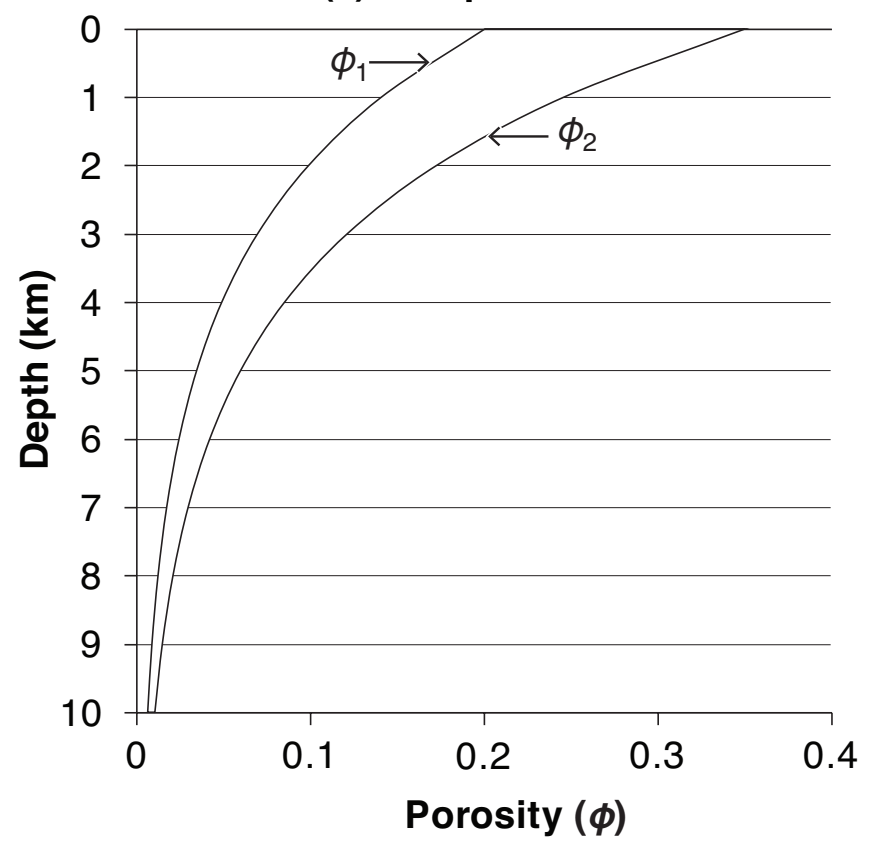

(b) Frictional $\mathrm{H}_{2}$

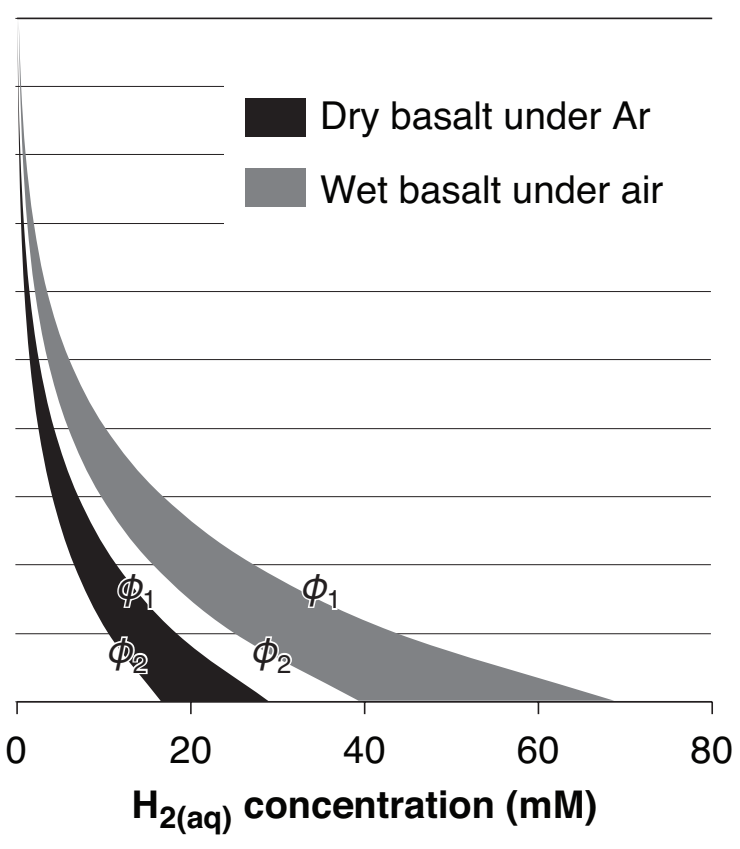

\section{FIGURE 7}

Approximate instantaneous seismogenic $\mathbf{H}_{2(a q)}$ concentrations after a Mars-quake as a function of depth and porosity below the surface. (a) Maximum $\left(\varphi_{2}\right)$ and minimum $\left(\varphi_{1}\right)$ porosity curves for martian crust proposed by Clifford et al. (2010). (b) Seismogenic (frictional) $\mathrm{H}_{2(\mathrm{aq})}$ concentrations in fault-zone groundwater according to the model from Hirose et al. (2011) and the porosity curves in (a), showing concentrations well above the threshold for microbial utility $(<<1 \mathrm{mM})$. The experiments of Hirose et al. $(2011,2012)$ provide two values of $\alpha$, an empirical coefficient used in the calculation (Equation 1); the black curve is obtained using $\alpha$ measured for dry (desiccated) basalt under argon gas; the grey curve is obtained using $\alpha$ measured for wet (water-saturated) basalt under air. Note that the saturation point of $\mathrm{H}_{2}$ in water is about $1 \mathrm{mM}$ under standard conditions. 